\title{
Microgrid Design for Remote Location in Chile using a Scenario-Based Methodology
}

1 Ruben Hidalgo, Bs ${ }^{1}$, Pablo Jacome, Bs ${ }^{2}$, Javier Urquizo, M.Sc ${ }^{1}$ and Guillermo Soriano, Ph.D ${ }^{1}$ Escuela Superior Politécnica del Litoral, Ecuador, rhidalgo@espol.edu.ec, jaurquiz@espol.edu.ec, gsorian@espol.edu.ec ${ }^{2}$ Universidad de Chile, Chile, psjacome@gmail.com

\begin{abstract}
This project presents a solution for the design of a microgrid in Jaboneria, located in Chile considering technical and economic aspects. For the design of the microgrid, the reference time of project is 20 years and a limited budget of USD $\$ 250836$, which is conceived as a Rural Electrification Budget. In order to produce a solution to the problem, HOMER PRO software is used. Sensitivity variables were taken into account, these include the variation of the electrical load, the state of charge of the batteries and renewable electricity generation systems. In addition other design parameters such as fuel cost, limitation residential electricity consumption, battery type, annual load profiles, fixed capital costs, etc.; were used. The cost of an Energy Management System (EMS) is not considered in the present analysis. Using HOMER, an optimal solution that combines the design parameters to find an efficient electrical energy production configuration that combines renewable energy sources (solar-wind), conventional generation (diesel) and battery power was produced, prioritizing clean energy. The optimal solution is obtained by evaluating the Net Present Value - NPC (USD \$) according to each of the scenarios generated by sensitivity variables. A schematic of the system components and the corresponding load profiles are shown. Then, the information concerning renewable resources that exist in the study area and the technical-economic information of each system components was introduced. In addition, parameters of model are established. A social plan of energy-efficient consumption and citizen participation is also proposed. Finally, a simulation and analysis of the results of the scenarios generated by sensitivity variables of the system are presented. The chosen solution had the lower value of NPC and it contains the final sizing of each of the system components. This solution has to be of less value than the base budget of the project.
\end{abstract}

Keywords-microgrid, HOMER, renewable energy, batteries, diesel generator

Digital Object Identifier

(DOI):http://dx.doi.org/10.18687/LACCEI2016.1.1.127

ISBN: 978-0-9822896-9-3

ISSN: $2414-6390$

$14^{\text {th }}$ LACCEI International Multi-Conference for Engineering, Education, and Technology: "Engineering Innovations for Global Sustainability", 20-22 July 2016, San José, Costa Rica. 


\title{
Microgrid Design for Remote Location in Chile using a Scenario-Based Methodology
}

\author{
Ruben Hidalgo, Bs ${ }^{1}$, Pablo Jacome, Bs ${ }^{2}$, Javier Urquizo, M.Sc ${ }^{1}$ and Guillermo Soriano, Ph.D ${ }^{1}$ \\ ${ }^{1}$ Escuela Superior Politécnica del Litoral, Ecuador, rhidalgo@espol.edu.ec, jaurquiz@espol.edu.ec, gsorian@espol.edu.ec \\ ${ }^{2}$ Universidad de Chile, Chile, psjacome@gmail.com
}

\begin{abstract}
This project presents a solution for the design of a microgrid in Jaboneria, located in Chile considering technical and economic aspects. For the design of the microgrid, the reference time of project is 20 years and a limited budget of USD \$250836, which is conceived as a Rural Electrification Budget. In order to produce a solution to the problem, HOMER PRO software is used. Sensitivity variables were taken into account, these include the variation of the electrical load, the state of charge of the batteries and renewable electricity generation systems. In addition other design parameters such as fuel cost, limitation residential electricity consumption, battery type, annual load profiles, fixed capital costs, etc.; were used. The cost of an Energy Management System (EMS) is not considered in the present analysis. Using HOMER, an optimal solution that combines the design parameters to find an efficient electrical energy production configuration that combines renewable energy sources (solar-wind), conventional generation (diesel) and battery power was produced, prioritizing clean energy. The optimal solution is obtained by evaluating the Net Present Value - NPC (USD \$) according to each of the scenarios generated by sensitivity variables. A schematic of the system components and the corresponding load profiles are shown. Then, the information concerning renewable resources that exist in the study area and the technical-economic information of each system components was introduced. In addition, parameters of model are established. A social plan of energy-efficient consumption and citizen participation is also proposed. Finally, a simulation and analysis of the results of the scenarios generated by sensitivity variables of the system are presented. The chosen solution had the lower value of NPC and it contains the final sizing of each of the system components. This solution has to be of less value than the base budget of the project.
\end{abstract}

Keywords-microgrid, HOMER, renewable energy, batteries, diesel generator.

\section{INTRODUCTION}

In most cities of the world, a big part of the electrical power supply comes from fossil fuels [1-3]. In remote areas (regional-rural communities and islands) of large urban centers, usually, there are no energy supply of national electrical networks [4-6]. The existence of a source of usable electrical energy is vital for the development of basic daily activities of the inhabitants of these locations. Certain localities are not able to connect to the distribution networks due to physical constraints (distance) and economics (high investment to bring distribution lines to the site) [7-11].

In remote areas of electrical distribution networks diesel generators are commonly used for electricity supply due to low installation cost, reliability and simple operation [12]. Costs of operation and maintenance (O\&M) of this type of machinery are very high [12-14]. The use of fuel and its transport from the supply terminal to the point of use represents logistic, economic efforts and significant environmental concerns [15-17].

Many simulation programs are being used for research and development of various technical-economic solutions for power supply in remote areas. These programs analyze the implementation of hybrid power systems [13-14, 18-20] and microgrids [21-24]. Research is focused on creating affordable solutions for supplying electricity for sites far from their national electrical networks.

This project shows a technical-economic solution for a microgrid that efficiently combines fossil fuel power generation, some renewable energy sources (solar and wind) [25-31] and a battery system. The solution presented seeks sustainability of the system in the long term (20 years lifetime of the project) with a limited budget of USD \$ 250836 (Rural Electrification Budget of $\$ 150$ million with exchange rate of USD \$ 1 to \$ 598). The \$ sign represents Chilean pesos, and USD \$ is used for representing United States dollars. For the simulation and evaluation of different configurations of energy sources available, the HOMER PRO software (Hybrid Optimization Model for Electric Renewable) is used. HOMER identifies the optimal solution in the planning of hybrid power systems where conventional generators, renewable energy sources and storage systems [32] are mainly used. The evaluation of the optimal solution runs through economic analysis of possible alternatives, choosing the most optimal under various different scenarios [33] generated by the sensitivity variables.

In this paper, an introduction on the importance of microgrids and the use of HOMER to design of these is given. A schematic of the system components and the information of load profiles are shown. Information concerning renewable resources in the area of study is entered with the technicaleconomic aspects of each of the system components. In addition, model parameters (economic and control) are established. A social plan of energy-efficient consumption and citizen participation is also proposed. The simulation and analysis of the results of each of scenarios generated by sensitivity variables of the system is presented, where the lower value solution of NPC and the final sizing of each of system components is given. This solution has to be of less value than the base budget of the project. Thus, this project is an opportunity to find an optimum technical economic solution that efficiently combine electricity generation with fossil fuel and some renewable energy sources (solar and wind), to supply electricity to the inhabitants of Jaboneria.

Digital Object Identifier (DOI): http://dx.doi.org/10.18687/LACCEI2016.1.1.127 ISBN: 978-0-9822896-9-3 ISSN: $2414-6390$

$14^{\text {th }}$ LACCEI International Multi-Conference for Engineering, Education, and Technology: "Engineering Innovations for Global Sustainability", 20-22 July 2016, San José, Costa Rica. 


\section{IDENTIFICATION OF THE PROBLEM}

The locality of Jaboneria belongs to the Commune of Canela in the Province of Choapa, Fourth Region of Chile (Fig. 1) [34]. There are 16 family residences located in the area. Local people are dedicated to agriculture, raising cattle, sheep, etc. This location is $16 \mathrm{~km}$ from the communal head, at a distance of 6 kilometers to the nearest electrical distribution network. It also has a rural school, soccer field and communal house (center of events or meetings). The concentration of family residences is not more than 500 meters of each other. Currently, inhabitants of Jaboneria not have the electrical power supply.

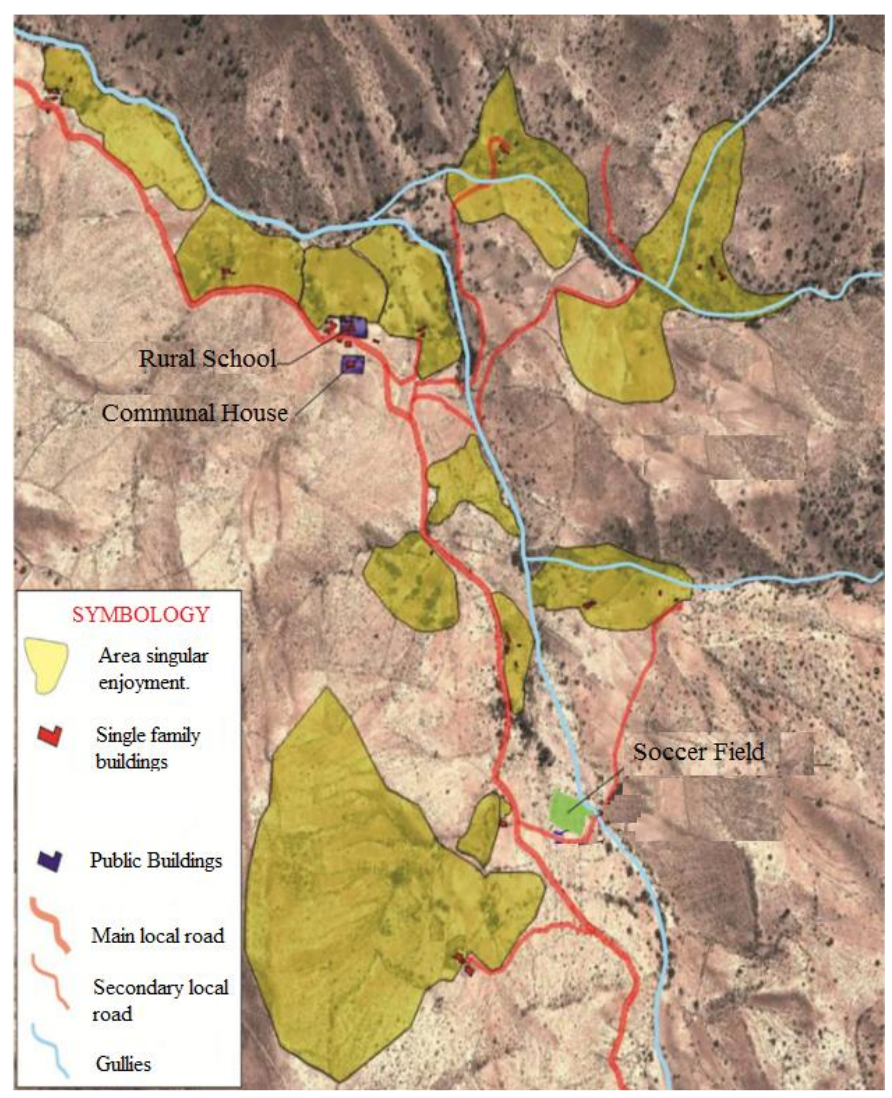

Fig. 1. Geographical location of locality Jaboneria.

This project aims to design a microgrid for the locality of Jaboneria. For generating a feasible solution considering technical and economic parameters, using HOMER PRO software. The design lifetime is proposed to 20 years and the following parameters were considered:

- Growth rate of load: Under the proposed scenario for the assessment, an annual consumption growth of $1 \%$ is considered. The load is comprised of residences, public services and users of productive sector.

- Additional projects: The lighting of the soccer field and a shared area between a rural school and the communal house are incorporated in the analysis.
- Limiting power consumption: For the first year, the monthly electricity consumption per residence must not exceed $100 \mathrm{kWh} /$ month.

- Private discount rate: 9\%, this value is estimated according to data from the Private Banking.

- The cost of fuel was assumed as a constant during this time.

- Costs of maintenance of diesel generator and batteries (only if it was required) are considered in USD \$150 per year, which are covered with the money collected on account of electricity consumption of the residences.

The analysis of alternatives of electrical generation involves acquisition of diesel generation and alternatives of generation with solar and wind resources. Also, a storage system involving Lead Acid $\mathrm{OPzV}$ type batteries, is considered.

Since the location where the microgrid will be installed doesn't have electrical power supply and because of the economic difficulties in the zone it is necessary to stablish a monthly rate for every house of $\$ 2000$. This value is relatively low in order to incentivize the community participation in the project. For the purposes of calculating the total energy costs, the cost of battery replacement was not considered. Other costs such as fuel, O\&M (operations and maintenance) are considered. It is assumed that there is a Rural Electrification Budget that sums \$ 150 million Chilean pesos. The exchange rate for dollars to be taken into account for this project is USD \$ 1 / \$ 598 [35].

\section{BLOCK DIAGRAM OF SYSTEM COMPONENTS}

The block diagram is shown in Fig. 2. This diagram indicates the system components that are analyzed in HOMER PRO software:

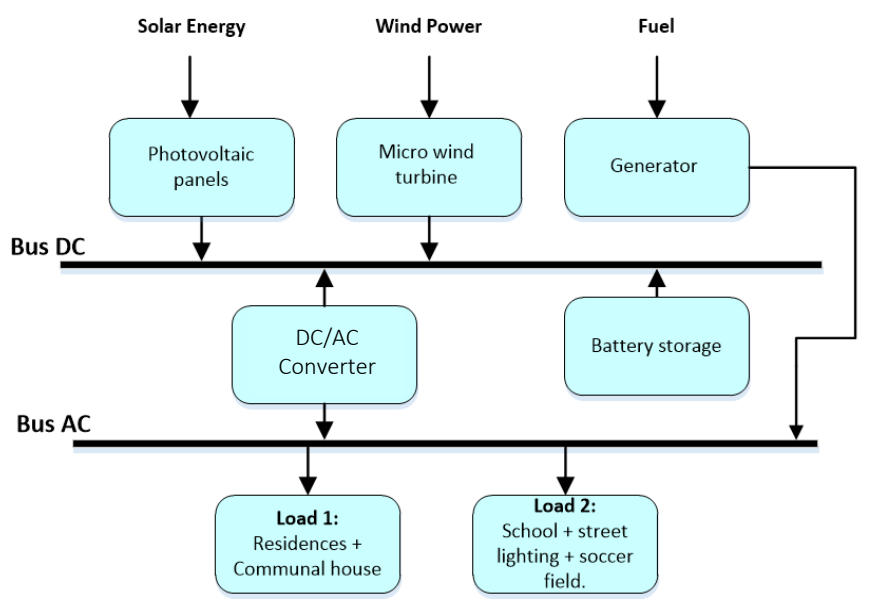

Fig. 2. Block diagram of system components.

14 ${ }^{\text {th }}$ LACCEI International Multi-Conference for Engineering, Education, and Technology: "Engineering Innovations for 


\section{ELECTRIC LOAD PROFILES}

In the locality of Jaboneria, the electrical load consists of the following items:

- Residential and communal house demand.

- Rural school demand.

- Demand of street lighting among communal house and rural school.

- Demand of street lighting of soccer field.

A residence has an average consumption of 4322 $\mathrm{kWh}$ /day and school $2781 \mathrm{kWh} /$ day. The communal house has an average rural consumption similar to a residence. In HOMER, the electrical load was divided by two, according to the priority of dispatch. The electrical load 1 has the highest priority dispatch and it is composed of a demand of residences and the communal house.

TABLE I

RESIDENTIAL + COMMUNAL HOUSE DEMAND CHARACTERISTICS

\begin{tabular}{|l|r|}
\hline Number of Residences (including Communal House) & 17 \\
\hline Peak demand & $6,49[\mathrm{~kW}]$ \\
\hline Duration of peak demand & $18: 00-22: 00$ \\
\hline Period of low demand & $00: 00-06: 00$ \\
\hline Load average & $3,98[\mathrm{~kW}]$ \\
\hline Average consumption per day & $73,85[\mathrm{~kW} / \mathrm{day}]$ \\
\hline Individual monthly consumption (1 residence x 30 days) & $130,32[\mathrm{kWh}]$ \\
\hline
\end{tabular}

For the first year, it is required that the load of each residence does not exceed $100 \mathrm{kWh} /$ month (currently 130.32 $\mathrm{kWh}$ ). To fulfill this objective, strategies for saving energy in homes should be implemented, such as:

- Allocation to each residence of saving light bulbs. This allow savings of $10 \%$ of the total load. Each residence must receive a total of 5 saving light bulbs each one of $18 \mathrm{~W}$.

- Allocation to each residence of refrigerators with standard "Energy Star" [36]. This technology allows savings of up to $20 \%$ energy [37]. The average monthly consumption of each refrigerator is roughly $24.6 \mathrm{kWh}$.

With the key components that are listed, energy savings of approximately $25 \%$ were projected. Characteristics of the load for the first year are estimated according to table II and the initial restriction of not exceeding the monthly consumption of $100 \mathrm{kWh}$ each residence is respected:

TABLE II

RESIDENTIAL + COMMUNAL HOUSE DEMAND CHARACTERISTICS

\begin{tabular}{|l|r|}
\hline Number of Residences (including Communal House) & 17 \\
\hline Peak demand & $5.36[\mathrm{~kW}]$ \\
\hline Duration of peak demand & $18: 00-22: 00$ \\
\hline Period of low demand & $00: 00-06: 00$ \\
\hline Load average & $2.31[\mathrm{~kW}]$ \\
\hline Average consumption per day & $55.37[\mathrm{~kW} / \mathrm{day}]$ \\
\hline Individual monthly consumption (1 residence x 30 days) & $97.7[\mathrm{kWh}]$ \\
\hline
\end{tabular}

The annual daily load profile of 16 residences and communal house is shown in Fig. 3. The x-axis corresponds to the hours and the $\mathrm{y}$-axis represents the $\mathrm{kW}$ of consumption.

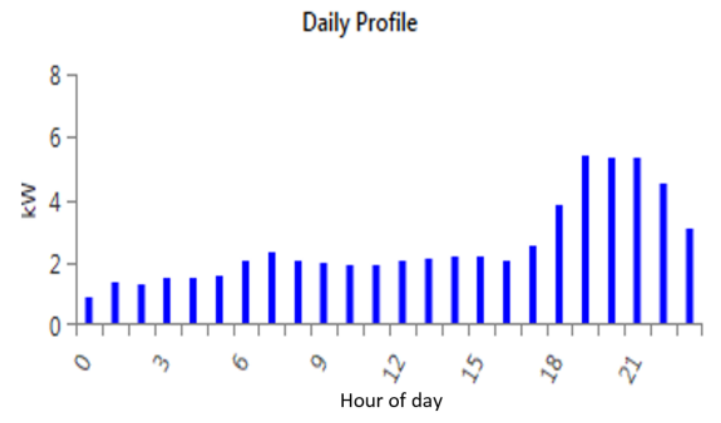

Fig. 3. Annual daily load profile of 16 residences an communal house

The Fig. 4 shows the frequency histogram of annual power consumption of the residences including the communal house.

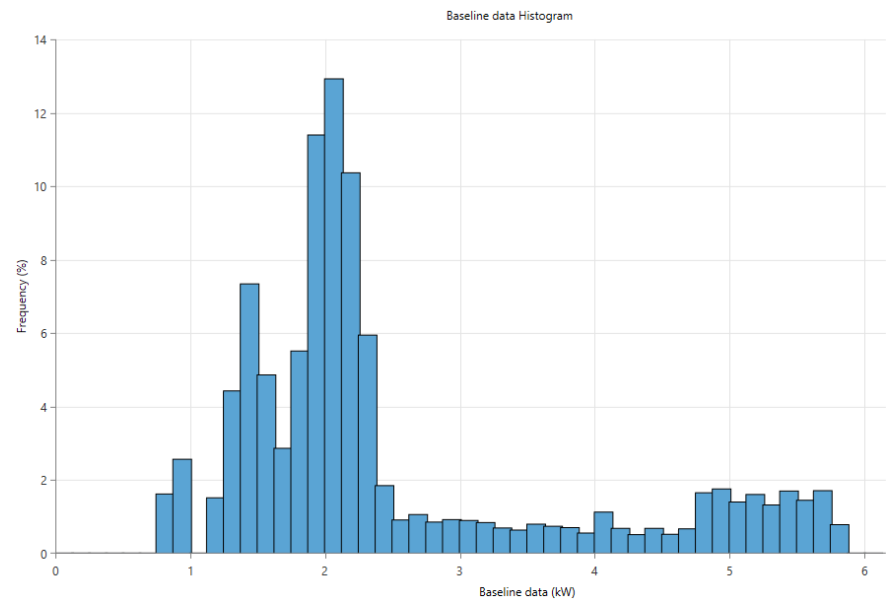

Fig. 4. Frequency histogram of annual power consumption of the residences and communal house

The demand for the rural school, street lighting and soccer field is characterized with the information presented in table III.

TABLE III

SCHOOL + STREET LIGHTING + SOCCER FIELD DEMAND CHARACTERISTICS

\begin{tabular}{|l|r|}
\hline Peak demand & 17 \\
\hline Load Average & $6,49[\mathrm{~kW}]$ \\
\hline Average consumption per day & $7.93[\mathrm{~kW} / \mathrm{d}]$ \\
\hline
\end{tabular}

In order to establish the characteristics of the demand for rural school, street lighting and soccer field, the design of the infrastructure of the power lines, power consumption of lighting (LED type) and the cost of these infrastructures was considered. The demand of the soccer field is assumed at a maximum value at between $19 \mathrm{~h} 00$ and $22 \mathrm{~h} 00$ on Saturdays and Sundays. In this project, the existing rules on area of street lighting in the Republic of Chile: "Norma para diseño de

$14^{\text {th }}$ LACCEI International Multi-Conference for Engineering, Education, and Technology: "Engineering Innovations for Global Sustainability", 20-22 July 2016, San José, Costa Rica. 
alumbrado público en sectores urbanos" [38] and "Electricidad. Especificaciones para luminarias y carreteras" [39-40] were taken into account.

The annual daily load profile of the rural school, the street lighting and soccer field can be seen in Fig. 5. The x-axis corresponds to the hours and the y-axis represents $\mathrm{kW}$ consumption.

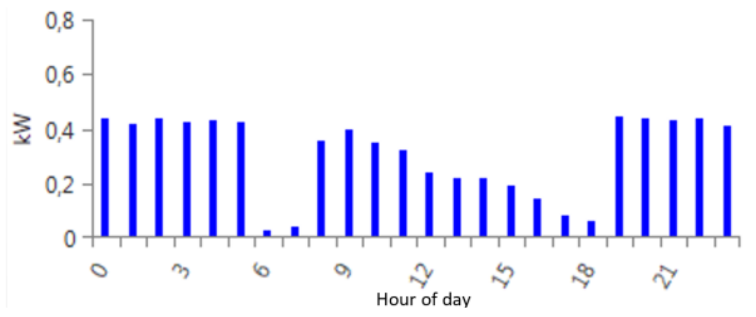

Fig. 5. Annual daily load profile of rural school +street lighting + soccer field

Fig. 6 shows the frequency histogram of annual power consumption of the above mention load profiles.

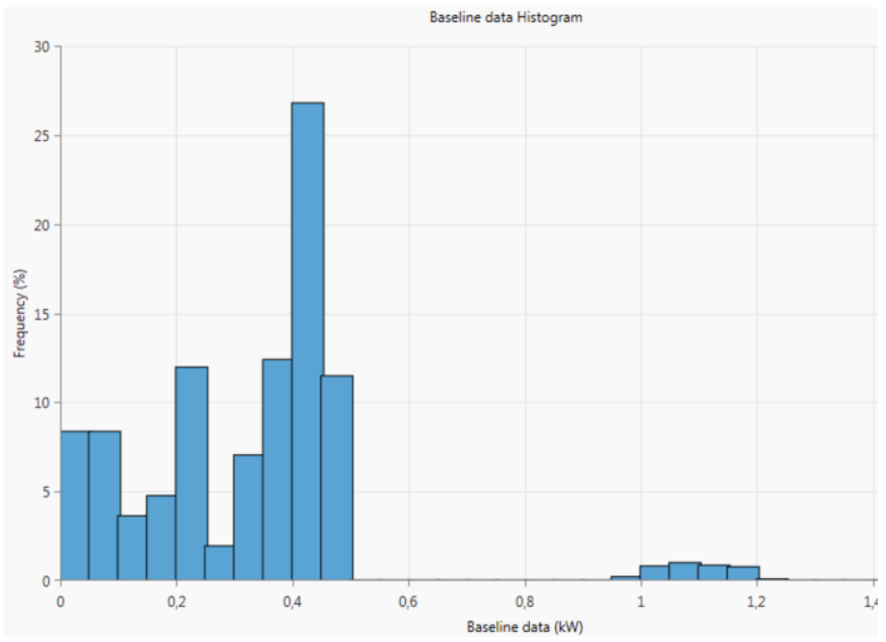

Fig. 6. Frequency histogram of annual power consumption of the rural school + street lighting + soccer field

\section{RENEWABLE RESOURCES}

The information regarding solar and wind resource in the area under study, is presented in this section. In addition the temperature of the location was also considered for the simulation and analysis.

\section{A. Solar Energy Resource}

The use of photovoltaic solar energy is vital for the design of this project. Ideally, it will be required to make in situ measurements in the candidate site, to gather accurate values of solar resource for the installation. In this project, the database "Explorer Solar Energy" [41] was used for the solar resource, because there was no information from meteorological stations available in Jaboneria. From the mentioned source, the monthly average global insolation in units of $\mathrm{kWh} / \mathrm{m}^{2}$, was gathered. It is worth noting that in this explorer, solar maps that have been generated from satellite data and atmospheric models can be found, for the period between 2003 and 2011, with a spatial resolution of one kilometer. The explorer was developed by the Department of Geophysics of the University of Chile for the Ministry of Energy of Chile and the GIZ (German Federal Government Agency specializing in technical cooperation for sustainable development around the world).

Once the monthly data was generated in the explorer, it was introduced into the software to be used for the estimation of production of the monthly and annual photovoltaic solar energy, as seen in figures 7 and 8.

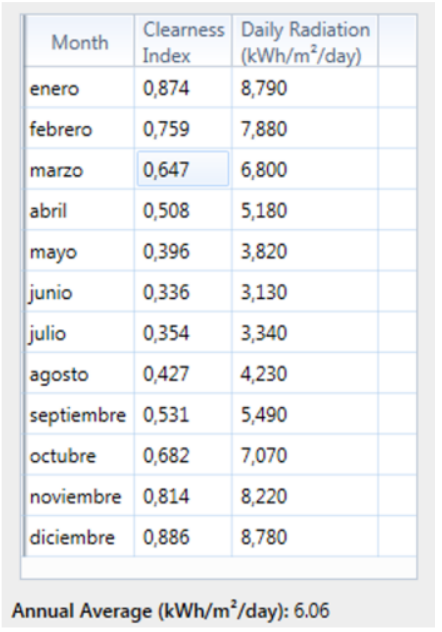

Fig. 7 Monthly horizontal levels of solar radiation at the location.

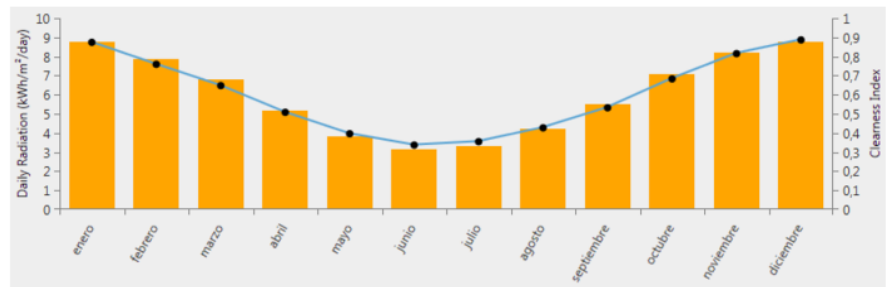

Fig. 8 Graphic representation of monthly horizontal levels of solar radiation at the specified location.

The annual horizontal level of solar radiation in Jaboneria is $6.06 \mathrm{kWh} / \mathrm{m}^{2} /$ day, as seen in figure 7 . This value is appropriate for the implementation of photovoltaic solar projects. From the data, it is noticeable that the solar resource is greater during the months from October to April. The month with the lowest level of solar radiation is June and the highest is January. HOMER automatically determines the level of Clearness Index [42] from the input data of explorer. It can also be seen in the aforementioned figures that the highest rate is 0,886 of clearness index for the month of December.

\section{B. Wind Energy Resource}

The average wind speed was obtained from the database of "Wind Energy Explorer" [43]. The explorer was developed by the Department of Geophysics of the University of Chile 
for the Ministry of Energy of Chile and GIZ. This one shows the most complete wind map for Chile, which was made from numerical simulations, which covers the whole territory from Arica to Chiloe, including Pascua Island. Monthly averages of wind speed are shown in figures 9 and 10.

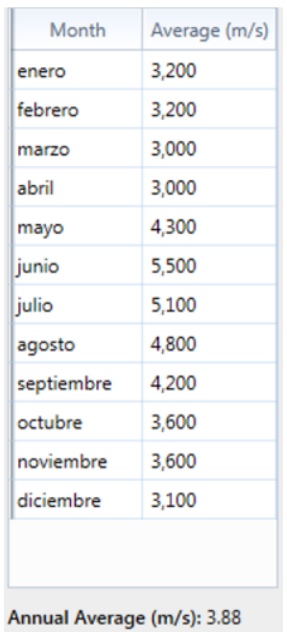

Fig. 9 Monthly averages of wind speed in the sector of Jaboneria.

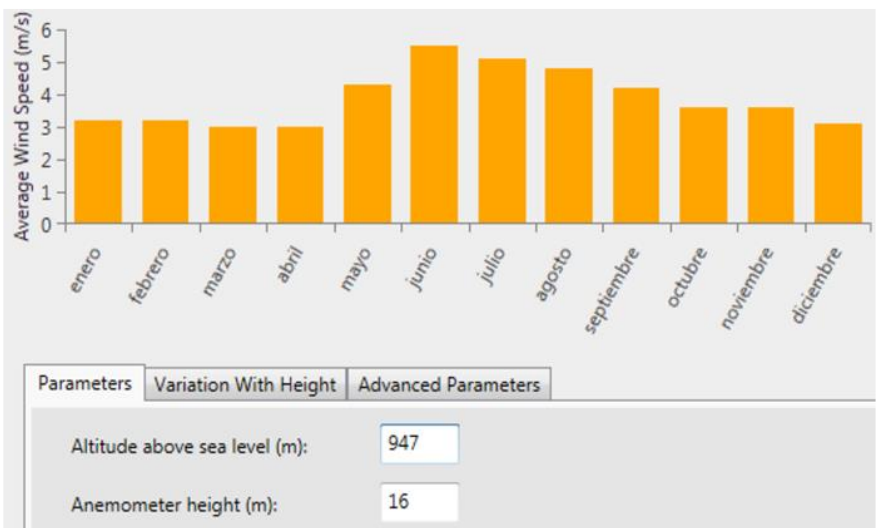

Fig. 10 Graphic representation of monthly averages of wind speed in the sector of Jaboneria.

The average annual wind speed is $3.88 \mathrm{~m} / \mathrm{s}$ at a height of 16 meters above the ground. Highest wind speed values occur from May to September with more than $4 \mathrm{~m} / \mathrm{s}$. Other months have wind speeds in the range of 3 to $4 \mathrm{~m} / \mathrm{s}$. Figure 10 shows that the height of wind measurements is 16 meters above the ground (947 meters above sea level).

From wind data entered into HOMER, a wind profile can be constructed. Fig. 11 shows that it is possible to obtain a speed of roughly $4.4 \mathrm{~m} / \mathrm{s}$ at a height of 50 meters from the ground (with the information gathered to 16 meters above the ground).

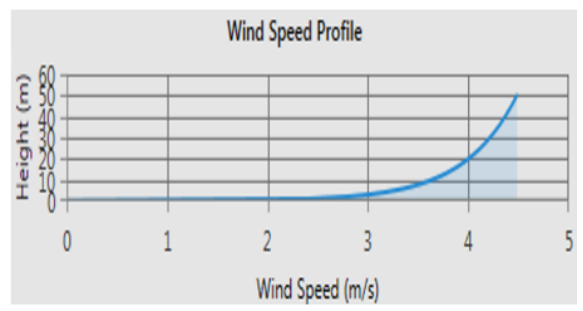

Fig. 11 Wind profile in Jaboneria.

The roughness length coefficient [44] is a parameter that sets characteristics of the terrain where the wind turbine system would be installed. This coefficient is also involved in the calculation of the wind profile. For this project, a coefficient of 0.01 meters, which is the right for an area of few trees [45], was used. The low density of trees was determined using satellite images available on Google Earth software.

Fig. 12 shows advanced parameters for the generation of synthetic data of wind speed (obtained in HOMER). The Weibull shape factor $\mathrm{k}$ is equal to 2 . Moreover, the correlation factor is equal to 0.85 which is the variability of the wind force from hour to hour. Diurnal pattern of wind force is 0.25 which reflects on how the force of the wind speed varies on a determined hour of day. According to the analysis of the data supplied by the Wind Energy Explorer [43], 15:00 is taken as the time of maximum wind speed. Concepts discussed in this paragraph appear in the section help of HOMER [46].

\begin{tabular}{|c|c|c|}
\hline Parameters & Variation With Height & Advanced Parameters \\
\hline \multicolumn{2}{|c|}{ Weibull K: } & 2 \\
\hline \multicolumn{2}{|c|}{$1 \mathrm{hr}$. autocorrelation factor: } & 0,85 \\
\hline \multicolumn{2}{|c|}{ Diurnal pattern strength: } & 0,25 \\
\hline \multicolumn{2}{|c|}{ Hour of peak windspeed: } & 15 \\
\hline
\end{tabular}

Fig. 12 Advanced parameters of the generation of synthetic data of wind speed.

\section{Temperature Resource}

Monthly averages of temperature were gathered from the database of METEONORM program [47]. This database is recognized worldwide and has been used in a variety of scientific publications. Figures 13 and 14 show the average monthly temperature values of the locality of Jaboneria. Months with temperatures below 10 degrees are from May to August. Also the month with the highest temperature is January with $22.28{ }^{\circ} \mathrm{C}$. The average annual temperature is $14.8{ }^{\circ} \mathrm{C}$. This feature is important for calculating the temperature of the photovoltaic solar panels. 


\begin{tabular}{ll} 
Month & $\begin{array}{l}\text { Daily } \\
\text { Temperature }\end{array}$ \\
\hline enero & 22,281 \\
febrero & 21,077 \\
marzo & 18,764 \\
abril & 14,191 \\
mayo & 9,938 \\
junio & 7,383 \\
julio & 7,014 \\
agosto & 8,905 \\
septiembre & 11,545 \\
octubre & 15,938 \\
noviembre & 18,465 \\
diciembre & 21,058
\end{tabular}

Fig. 13 Monthly averages of temperature in Jaboneria.

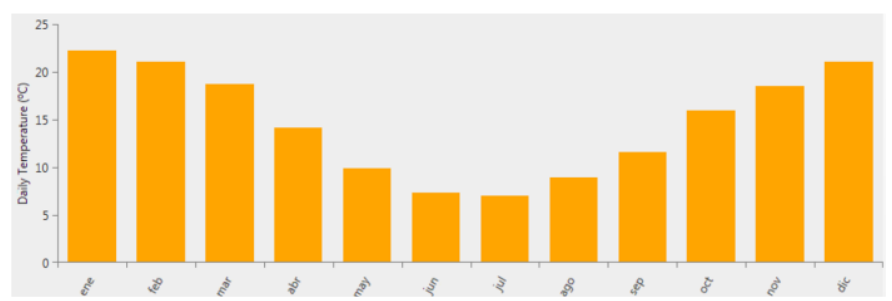

Fig. 14 Graphic representation temperature in Jaboneria.

\section{SELECTION OF SYSTEM COMPONENTS}

This project combines sources of electricity generation from renewable energy and fossil fuels. The energy produced must be sufficient to supply electricity to residences, communal house, rural school, soccer field and others. As renewable energy sources for electricity generation, the usage of photovoltaic solar panels and micro wind turbine are analyzed. As conventional energy source (use of fossil fuels), a diesel generator was considered. The use of renewable energy sources is complemented with a battery bank as a storage system [48-49]. The battery bank, among one of its functions, reduces problems associated with the intermittent nature of renewable energy sources [50-51].

The main components of the micro grid were mentioned in previous sections. They are PV solar panels, a micro wind turbine, a diesel generator, a battery bank and inverter.

The component selection criteria is based on technical requirements, investment costs and O\&M costs. Information regarding investment costs is taken from a research conducted at the local and international market. This work consisted in verifying offers from several suppliers. The costs of maintenance of equipment are based on several interviews with national and international specialists. This paper assumes that the cost of each component is directly proportional to the number of purchased components.

\section{A. Photovoltaic solar panels}

After verification of the available prices locally and internationally (CIF prices), the investment cost was determined to be within the range of USD $\$ 2800$ per $\mathrm{kW}$ installed of PV panels. Installation costs are around USD $\$ 2200$ per $\mathrm{kW}$ considering voltage regulators, installation accessories, costs of permission and logistic, etc. The reference value, given by NREL (National Renewable Energy Laboratory), for an installation cost is of USD $\$ 4690$ per $\mathrm{kW}$ [52]. The value used for this project was USD $\$ 5000$ per $\mathrm{kW}$.

Photovoltaic solar panels have a high capital cost but the cost of maintenance is lower than a micro wind turbine. The photovoltaic panel system does not have a mechanical solar tracking system so there are not O\&M costs associated with this system. The lifetime of each of the panels is about 20 years so the replacement cost is USD $\$ 0$. Photovoltaic solar panels are connected to a 380 VDC bus by a solar controller that has a system maximum power point tracking (MPPT).

\section{B. Micro wind turbine}

The size of the micro wind turbine used for the system design had a rated power of $3 \mathrm{~kW}$. The cut in speed is $3 \mathrm{~m} / \mathrm{s}$, the rated speed is $15 \mathrm{~m} / \mathrm{s}$ and the cutting out speed is $25 \mathrm{~m} / \mathrm{s}$. All technical data of the wind turbine was entered to HOMER. The HOMER space search are: 0,1 and 2 wind turbines. The power curve of the wind turbine is shown in Fig. 15. Note that when the wind speed equals the nominal speed, the turbine produces $3 \mathrm{KW}$. The device of rectification and regulation of wind turbine allows the transfer of electrical power to the DC bus voltage $(380 \mathrm{~V})$.

The lifetime of a wind turbine is approximately 10 years. The capital cost of one unit is around USD \$10000. Replacement cost is USD $\$ 6000$ without considering the turbine tower and accessories. The wind turbine and the turbine tower require a maintenance program, which involves lubrication, replacement of bearings, cleaning, coatings of surface of blades and many other tasks specified in the respective operating manual. If the wind turbine is located in a distant place and at a height above the ground, its maintenance can increase the total cost of system. Besides the excessive time that it could take, which may affect the reliability of the total system. For the purpose of this paper, maintenances are not specifically detailed and it is considered that the operating and maintenance costs are valued in USD \$300/year.

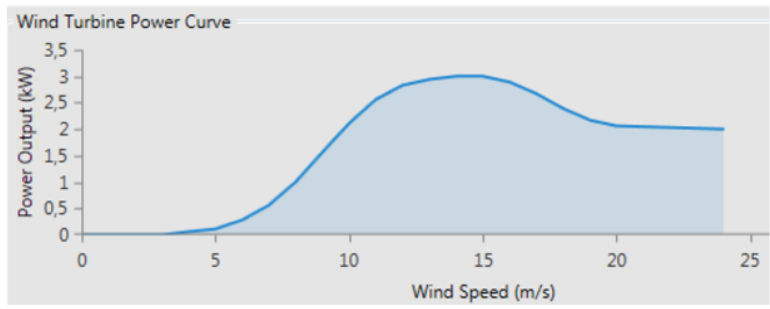

Fig. 15 The power curve of the wind turbine.

\section{Diesel generator}

The costs of a diesel generator vary significantly depending on its size. Small units have much higher capital cost that bigger units. The rated power for the generator is

$14^{\text {th }}$ LACCEI International Multi-Conference for Engineering, Education, and Technology: "Engineering Innovations for 
considered at $10 \mathrm{~kW}$ which was available in the search space of HOMER. The size 0 indicates that the system is $100 \%$ renewable and the micro grid operates without the generator.

The lifetime of the generator is considered in 20 years with a minimum rate of load adjusted at $25 \%$. The capital cost of the proposed diesel generator is USD $\$ 1000 / \mathrm{kW}$, while its replacement and O\&M costs are 0 . The cost of O\&M is obtained from the money collected on account of electricity consumption of residences which is an approximate value of USD \$150/year. During the time of the preparation of this paper, the price of diesel fuel is around USD $\$ 1.25 / \mathrm{L}$ (November-2015) and has an upward trend. This value includes logistics costs, mainly cost of transport and storage of fuel in locality of Jaboneria.

\section{Batteries}

The storage capacity of batteries gives to the present system approximately 48 hours of autonomy. The nominal voltage of each battery is $2 \mathrm{VDC}$ and the capacity is $200 \mathrm{Ah}$. The configuration is formed by one string of 192 batteries in series. The minimum state of charge is set to $20 \%$. This string is connected to DC bus voltage $(380 \mathrm{~V})$.

The capital cost of a battery includes the value of the battery, the cost of installation, logistics costs of customs and transport to the locality of Jaboneria. The referential price of each battery is USD \$83 (CIF price in the port of Valparaiso, Chile). The installation cost value is USD \$11 per battery considering costs of accessories and rack. Logistics and customs costs are USD $\$ 8$ per battery. Here are not considered costs of replacement of batteries. The total capital cost is USD $\$ 100$ for each battery. The O\&M cost is USD \$0/year because batteries are sealed and do not require maintenance.

\section{E. DC/AC Converter}

This equipment is required for interconnection between DC-bus and AC-bus. It transforms the DC current to AC and vice versa [53-55]. It allows charging and discharging batteries by the AC bus. One $10 \mathrm{~kW}$ unit is modeled, with an efficiency of $85 \%$ for the inverter and rectifier. A useful lifetime of 20 years is estimated. The inverter does not require additional O\&M because it is a solid state component with a low failure rate. Costs obtained in the analysis of market reflect a CIF price (in the port of Valparaiso) of USD \$5000 for a $10 \mathrm{~kW}$ converter.

\section{OPERATIONAL PARAMETERS AND FINANCIAL COST}

Model parameters are established based on: economic parameters, control system and operating restrictions.

The economic parameters are:

- Discount rate: $9 \%$

- Expected Inflation: 0\%

- Project Lifetime: 20 years

- Fixed capital costs of the project: USD \$ 64390.

- Fixed costs of O\&M of the project: USD \$ 100 per year.
Fixed capital costs were determined taking into account the cost of each equipment, street lighting infrastructure, energy-efficient equipment (refrigerators, saving light bulbs, etc.), transportation costs, electrical work, etc. This study does not take into account the cost of equipment Energy Management System (EMS) of the microgrid [56-57].

The parameters of the control system are:

- Type of minimization, [19] are between the planning options of a microgrid taking into account the economic factor.

- Dispatch strategy: The case of load following (LF) and cycle charging (CC) are analyzed. For the load following dispatch, the diesel generator produces electrical energy in order to meet the primary demand. The cycle charging strategy is focused on the working at nominal power a diesel generator in order to meet primary demand but too charging the system batteries. For the project, the state of charge: 20, 40 and $60 \%$ were assumed.

- Simulation intervals are of 1 hour (8760 hours per year).

The parameters of operating restrictions are:

a) Reserves:

- $10 \%$ of the total load.

- $25 \%$ of the total output power for generation with photovoltaic solar power.

- $50 \%$ of the power output by wind power generation.

b) Maximum cutting capacity: $0 \%$.

\section{SOCIAL PLAN OF ENERGY-EFFICIENT CONSUMPTION}

In this project, a social plan of energy-efficient consumption for inhabitants of the area is also presented. The objective of this plan is to promote that the member of the community become active parties for the overall operation of the project. The plan consists in the supply of 16 refrigerators to same number of families. Each of these refrigerators consume low electrical energy (class A), with an average monthly energy consumption of approximately $24.60 \mathrm{kWh}$. In addition, the refrigerator must comply with Official Chilean Standard NCh3000.of2006 [58]. The use of old refrigerators greatly increase the electrical power consumption by about $60-70 \%$ in each residence [59].

Similarly, each family will be given five saving light bulbs. Like refrigerators, these bulbs must meet the Chilean standards [58]. Each energy saving bulb consumes $18 \mathrm{~W}$, but can one illuminate the equivalent of an incandescent light bulb of $100 \mathrm{~W}$. This bulb has a cost about USD \$ 2 .

With the delivery of refrigerators and saving light bulbs, the aim is for reducing the electrical demand of the site. It also seeks to improve the quality of life of inhabitants, in order to have sufficient lighting and preservation of food. The values of refrigerators and light bulbs are included in fixed capital costs of the project. 


\section{CITIZEN PARTICIPATION}

Certain activities must be coordinated with the community for the overall operation of the system. A direct contact with the leaders of the community has to be implemented in order to ensure the overall knowledge of the energy saving plan.

The system of electrical production proposed in this project is centralized, which facilitates the microgrid operation. The protection of equipment and infrastructure have to be performed by people in the locality. On the other hand, instructions must be given for a basic maintenance of the equipment. These maintenances are: cleaning of photovoltaic solar panels, loading fuel to the generator, changing of fuel filters, changing of saving light bulbs, etc. Costs associated with these activities are savings for the project.

\section{ANALYSIS OF RESULTS}

Income obtained on account of electricity consumption of the 16 residences give a monthly amount of USD \$ 53.51 (\$ 32000 to rate USD \$ 1 to $\$ 598$ ). During the first year of operation of the microgrid, the system is going to collect the amount of USD \$ 642.14 and during 20 years approximately the amount of USD \$ 12842.80. This money is sufficient to cover O\&M costs of diesel generator. Moreover, if the maintenance of battery and converter are required, these should also be covered.

For the simulation of the different configurations of power sources and the determination of the optimal solution, HOMER PRO software is used. The analysis of the results attempt to determine the following important points:

- The more efficient configuration with the lowest value of NPC without exceeding the base budget of project.

- The unique configuration of components (PV/Battery/wind turbine/Diesel Generator) with their respective sizes. The solution with the lowest NPC provides the information for the system.

In the above requirements, it was determined that the demand will increase by $1 \%$ annually. In order to account for this increment in HOMER PRO for 20 years, a recommendation found in the website HOMER in area of FAQ (frequently asked questions), was used [60]. The simulation runs with various load values corresponding to each of the years of the project lifetime.

The factor that decides the best option cost effective is based on the value of the NPC (net present value) which allows comparison between different investment scenarios; this is to compare long-term projects, measure cash flows and income in terms of the current value [61-62]. The maximum restriction of NPC of each configuration is USD \$ 250836 (\$ 150 million with exchange rate of USD \$ 1 to \$598). The general schematic of HOMER microgrid, by which the respective simulations were performed is shown in figure 16 . The best solutions given the criteria set by the project are:

- Configuration 1: Photovoltaic Solar Panel/diesel generator/batteries/converter.

- Configuration 2: Photovoltaic Solar Panel/Micro wind turbine/diesel generator/batteries/converter.

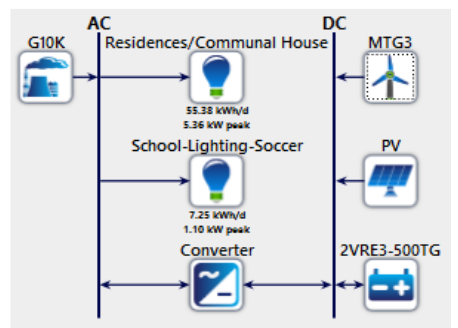

Fig. 16 General schematic of HOMER microgrid.

The simulation runs for 20 load values corresponding to total values for each year of the project lifetime and 3 minimum state of charge (20, 40 and $60 \%)$. The total load per year is formed by the electric load 1 and 2 . The electrical load 1 represents the load of 16 residences and communal house. The electrical load 2 contains the load values of the rural school, street lighting and soccer field. The table IV can verify simulation results for different configurations based on three load values: demand for the first year, demand in the year 10 and demand in the year 20 .

The optimal configuration is obtained from the demand in the year 20, the results are:

- Power by photovoltaic solar panels: $14 \mathrm{KWp}$

- Power of micro wind turbine: $0 \mathrm{~kW}$

- Power of diesel generator $10 \mathrm{KW}$

- Power of Converter: $10 \mathrm{KW}$

- Number of batteries: 192

TABLE IV

PARAMETERS OBTAINED FOR THE YEARS OF THE PROJECT LIFETIME

\begin{tabular}{|c|c|c|c|c|c|c|c|c|c|c|c|c|c|c|c|}
\hline$\underset{\partial}{\vec{d}}$ & 青 & 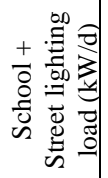 & 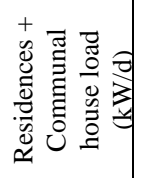 & $\begin{array}{l}\frac{\infty}{d} \\
\frac{1}{2} \\
2 \\
2 \\
2\end{array}$ & 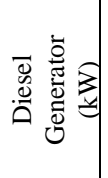 & 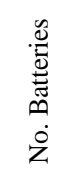 & $\begin{array}{l}\overrightarrow{ \pm} \\
\stackrel{0}{0} \\
\stackrel{3}{0} \\
ن\end{array}$ & 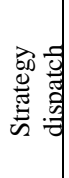 & 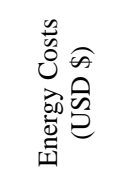 & 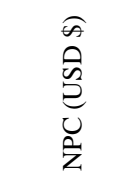 & 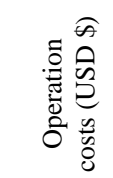 & 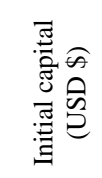 & 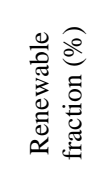 & 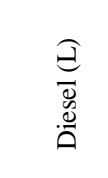 & 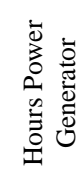 \\
\hline 1 & 20 & 55.38 & 7.248 & 12 & 10 & 192 & 10 & LF & .93695 & 195499.9 & 4043.35 & 158590 & 09.218 & 3154.08 & 2380 \\
\hline 10 & 20 & 59.96 & 7.927 & 14 & 10 & 192 & 10 & LF & 0.8983 & 203188.6 & 3790.16 & 158590 & 73.144 & 2952.13 & 2185 \\
\hline 20 & 20 & 66.7 & 8.576 & 14 & 10 & 192 & 10 & LF & 0.8538 & 215226.5 & 5108.87 & 158590 & 67.17 & 4007.09 & 2946 \\
\hline
\end{tabular}

$14^{\text {th }}$ LACCEI International Multi-Conference for Engineering, Education, and Technology: "Engineering Innovations for Global Sustainability", 20-22 July 2016, San José, Costa Rica. 
In Fig. 17, we can revise the summary of values of initial capital (USD \$ 168590) and fuel (USD \$ 45724) of the different entries of project during 20 years. It can be seen that the higher initial investment corresponding to photovoltaic solar panels. The decision to invest in photovoltaic solar panels, was based on the high solar potential in the north of Chile. The second investment value corresponds to "other" where fixed costs are included and this spending is done in year 1. Overall, the project spends USD \$100 per year in O\&M of the entire system. During 20 years, the total cost for this service is USD \$ 912.85. It is determined that the NPC of the project is USD \$ 215227. This value is lower than the base budget. It demonstrates that the system is technically and economically feasible.

\begin{tabular}{lrrrrrr}
\hline \multicolumn{1}{c}{ Component } & \multicolumn{1}{c}{ Capital (\$) } & Replacement (\$) & O\&M (\$) & \multicolumn{1}{c}{ Fuel (\$) } & \multicolumn{1}{c}{ Salvage (\$) } & \multicolumn{1}{c}{ Total (\$) } \\
\hline PV1k(4)250) & $\$ 70,000.00$ & $\$ 0.00$ & $\$ 0.00$ & $\$ 0.00$ & $\$ 0.00$ & $\$ 70,000.00$ \\
GENSET SILENT 10KW & $\$ 10,000.00$ & $\$ 0.00$ & $\$ 0.00$ & $\$ 45,724.00$ & $\$ 0.00$ & $\$ 55,724.00$ \\
Discover 2VRE3-500TG & $\$ 19,200.00$ & $\$ 0.00$ & $\$ 0.00$ & $\$ 0,00$ & $\$ 0.00$ & $\$ 19,200.00$ \\
Converter & $\$ 5,000.00$ & $\$ 0.00$ & $\$ 0.00$ & $\$ 0.00$ & $\$ 0.00$ & $\$ 5,000.00$ \\
\hline Other & $\$ 64,390.00$ & $\$ 0.00$ & $\$ 912.85$ & $\$ 0.00$ & $\$ 0.00$ & $\$ 65,303.00$ \\
\hline System & $\$ 168,590.00$ & $\$ 0.00$ & $\$ 912.85$ & $\$ 45,724.00$ & $\$ 0.00$ & $\$ \$ 215,227.00$ \\
\hline
\end{tabular}

Fig. 17. Summary if costs for configuration 1

In figure 18 , the monthly percentage of renewable energy by component in the system is shown. The optimal system determined a $67 \%$ penetration of renewable energy (table IV) due to the high solar potential of the area. It can also verify that during months of high solar radiation, diesel generator works less. In months of July and August, the diesel generator is used at a higher rate than the photovoltaic solar system due to lack of sunshine during these months.

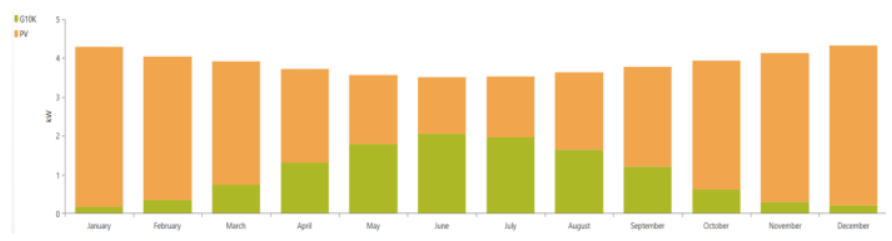

Fig. 18. Monthly percentage of renewable energy by component

In figure 19, the diesel consumption on a monthly time scale is shown. This can identify that months of higher average daily consumption of diesel are months of lowest solar radiation. This trend is precisely because in these months the diesel generator is most commonly used.

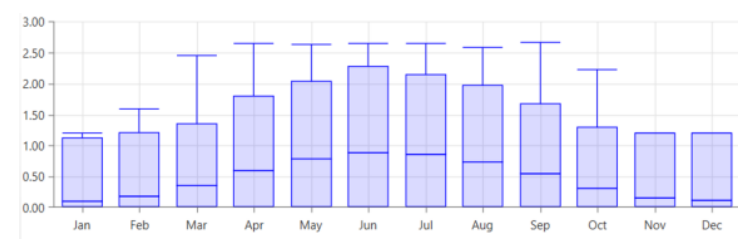

Fig. 19. Diesel consumption on a monthly time scale

The great solar potential in the area also generates excess electricity in months of higher radiation. In figure 20, we can see one day of January as electricity generation through photovoltaic solar panels could exceed the demand requirements.

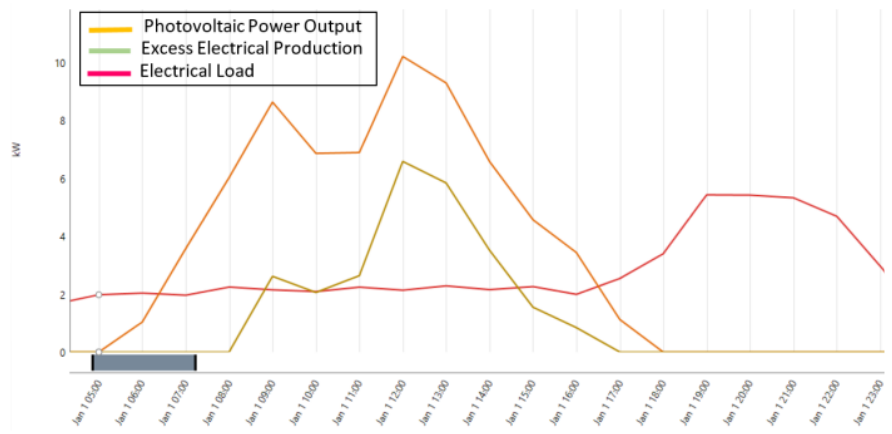

Fig. 20. A random day in January with decent solar potential

In months of lowest solar radiation, the demand is supplied with electrical power from the diesel generator and batteries. In figure 21 the difference in generation is shown. An analysis of figures 20 and 21 identifies that the system efficiently exploit the available energy sources. Renewable energy sources have priority over diesel generator. By reducing diesel consumption, the project becomes sustainable in its lifetime due to the less expenditure in economic resources using solar energy. Although the sensitivity analysis gives different values in excess energy produced, these values correspond to the large amount of solar energy available in the area.

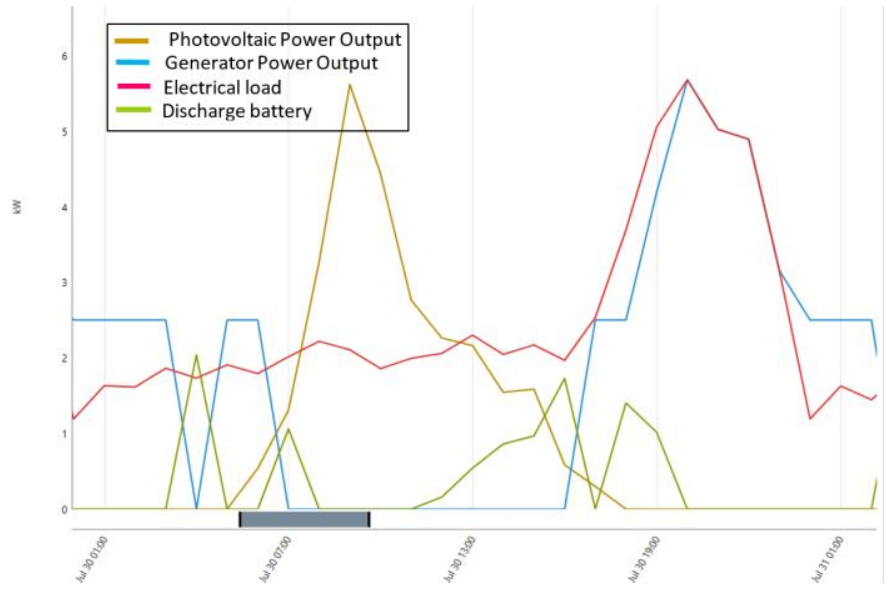

Fig. 21. A random day in July with low solar potential.

The configuration 2 consists in the inclusion of a micro wind turbine. This configuration has an NPC of USD \$ 225136. This value is lower than base budget, however, the use of a micro wind turbine does not generate neither the $10 \%$ of the energy of system due to the low values of the wind resource in the area. Fig. 22 shows the production of wind power in a day in June. The month of June has the highest average wind speed of year. To optimize spending, it was decided that this solution, although it is only $5 \%$ higher than implemented in configuration 1, requires additional logistic of

$14^{\text {th }}$ LACCEI International Multi-Conference for Engineering, Education, and Technology: "Engineering Innovations for Global Sustainability”, 20-22 July 2016, San José, Costa Rica. 
maintenance which can hinder the operation of the system in the future. This solution is not chosen.

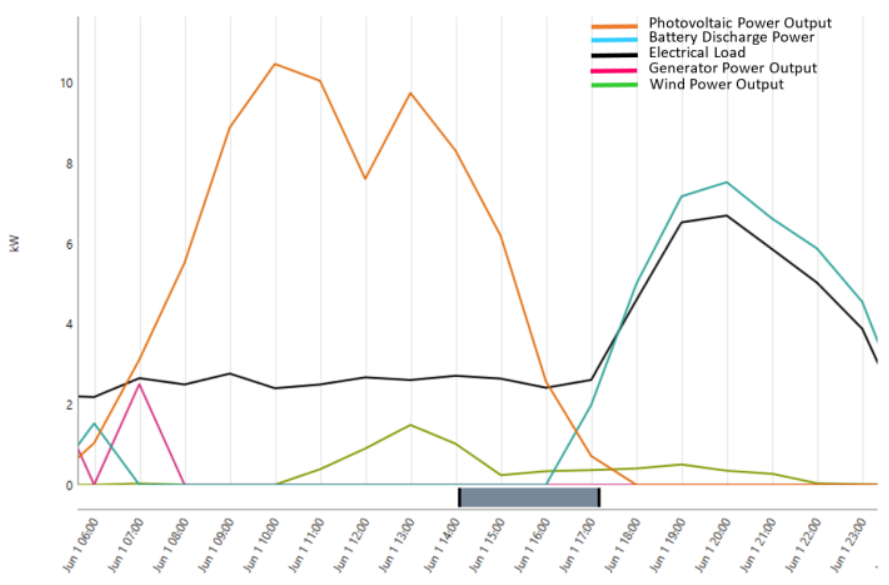

Fig. 22. Wind generation power in a day in June.

\section{CONCLUSIONS}

In this project, the robust solution was selected based on sensitivity analysis on different scenarios. The sensitivity variables that generated the scenarios were: the electrical load, the state of charge of battery, conventional and renewable energy sources.

The PV/Battery/Diesel Generator configuration provides the solution most reliable and cost-effective than any other type of configurations shown in simulations. Given the analysis provided, the best configuration for this paper consists of $14 \mathrm{kWp}$ photovoltaic solar panel array, $10 \mathrm{~kW}$ diesel generator, $10 \mathrm{~kW}$ power converter and 192 batteries (2V-205 Ah per unit). The NPC of this configuration was USD \$ 215227. This value is approximately 5\% cheaper than configuration 2 (PV/Battery/wind turbine/Diesel Generator). The inclusion of a wind turbine in this configuration generates distortions in the use of diesel generator. The distortions were related to the low values of wind speed in the area and its intermittence. The diesel generator and batteries would be used more times to assist the wind turbine in order to keep the load powered.

The income collected for the electricity consumption of the 16 residences produces a monthly amount of USD \$ 53.51 (\$ 32.000 to rate USD \$ 1 to \$ 598). During the first year of operation of the microgrid, the system is going to collect the amount of USD \$ 642.14 and during 20 years approximately the amount of USD $\$ 12842.80$. This money is sufficient to cover O\&M costs of diesel generator. Moreover, if the maintenance of battery and converter are required, these should also be covered.

In this project, a value of USD \$ 1.25 (\$ 748.5) per liter of diesel, was taken into account. This price includes its cost of transport to the site. Actually, the price per liter of diesel in the Commune of Canela is USD \$ 0.84 (\$ 501) [63], which is near to the locality of Jaboneria. The fuel does not take into account values of sensitivity and if an unexpected increment in costs occurs during projected lifetime of 20 years, it could also be covered by income obtained for electricity consumption of the 16 residences or the difference of the Rural Electrification Budget allocated to the development of this project (USD \$ 250836 - USD \$ $225136=\$ 25700$ USD).

The value that affects the most to the NPC is the cost of diesel. The NPC includes all costs associated with the project lifetime. In the first configuration with less NPC, the initial investment cost is very high. The latter is because of the nature of the solution implemented due to $67 \%$ penetration of renewable energy. Typical renewable energy projects have a high initial cost but low cost of operation. The implementation of this solution (result of this study) could provide to the locality of Jaboneria a sustainable solution over time and help to reduce pollutant emissions from burning fossil fuels.

Based on the optimal solution obtained within the economic limit established, the connection of microgrid with electrical distribution network is not analyzed.

The simulation in HOMER PRO takes as a reference that the system controller selects the solution with the lowest NPC, however this presumption does not apply in real control systems. The real control system of a microgrid is known as EMS (Energy Management System) and control decisions of dispatch of generators (renewable or conventional). It varies according to a logic of programming that are not necessarily based in the value of NPC.

HOMER does not allow the change in load during the lifetime of project. The values of NPC assume that demand will be fixed throughout the period of lifetime of project. In the present work, a load profile for each year of the project was performed and the year with the most load consumption was chosen. From this year, the annual load was increased $1 \%$ per year until $20^{\text {th }}$ year. These load values were established as demands for each of the 20 years. These values were used as sensitivity variables for electrical load 1 and electrical load 2, and thus the optimum solution was found among all simulated scenarios.

\section{REFERENCES}

[1] M. Rasoul, H. Abdi, S. Rezaei, and H. Rahimzadeh, "Demand side management and charging and discharging for multiple phevs to reduce cost and reduce fossil fuel using game theory in smart grid," in Environment and Electrical Engineering (EEEIC), 2015 IEEE 15th International Conference on, June 2015, pp. 128-132.

[2] W. Zghal, G. Kantchev, and H. Kchaou, "Determination of the exploitable solar energy for electricity generation using the photovoltaic systems," in Renewable Energies and Vehicular Technology (REVET), 2012 First International Conference on, March 2012, pp. 43-48.

[3] US Department of Energy. (2015, November) Fossil. [Online]. Available: \{http://www.energy.gov/science-innovation/energy-sources/fossil \}

[4] R. Gogula, "A sustainable hybrid/ off grid power generation systems suitable for a remote coastal area in oman," in GCC Conference and Exhibition (GCCCE), 2015 IEEE 8th, Feb 2015, pp. 1-6.

[5] E. Addo, J. Asumadu, and P. Okyere, "Optimal design of renewable hybrid energy system for a village in ghana," in Industrial Electronics and Applications (ICIEA), 2014 IEEE 9th Conference on, June 2014, pp. $1520-1526$.

[6] A. Gupta, R. Saini, and M. Sharma, "Modelling of hybrid energy system for off grid electrification of clusters of villages," in Power Electronics,

$14^{\text {th }}$ LACCEI International Multi-Conference for Engineering, Education, and Technology: "Engineering Innovations for 
Drives and Energy Systems, 2006. PEDES '06. International Conference on, Dec 2006, pp. 1-5.

[7] J. Villumsen, G. Bronmo, and A. Philpott, "Line capacity expansion and transmission switching in power systems with largescale wind power," Power Systems, IEEE Transactions on, vol. 28, no. 2, pp. 731-739, May 2013.

[8] F. Zhang, Z. Hu, and Y. Song, "Mixed-integer linear model for transmission expansion planning with line losses and energy storage systems," Generation, Transmission Distribution, IET, vol. 7, no. 8, pp. 919-928, Aug 2013.

[9] S. Hosseini, "Transmission network expansion planning in the competitive environment, a reliability based approach," in European Energy Market (EEM), 2012 9th International Conference on the, May 2012, pp. 1-6.

[10]F. Thiam and C. DeMarco, "Application of node centrality in transmission expansion planning under uncertainty," in North American Power Symposium (NAPS), 2014, Sept 2014, pp. 1-6.

[11]V. Balijepalli and S. Khaparde, "Novel approaches for transmission system expansion planning including coordination issues," in Power and Energy Society General Meeting, 2010 IEEE, July 2010, pp. 1-7.

[12]N. Mendis, K. Muttaqi, S. Sayeef, and S. Perera, "A control approach for voltage and frequency regulation of a wind-diesel-battery based hybrid remote area power supply system," in IECON 2010 - 36th Annual Conference on IEEE Industrial Electronics.

[13]A. Helal, R. El-Mohr, and H. Eldosouki, "Optimal design of hybrid renewable energy system for electrification of a remote village in egypt," in Communications, Computing and Control Applications (CCCA), 2012 2nd International Conference on, Dec 2012, pp. 1-6

[14]M. Nejad, M. Radzi, M. Kadir, and H. Hizam, "Hybrid renewable energy systems in remote areas of equatorial countries," in Research and Development (SCOReD), 2012 IEEE Student Conference on, Dec 2012, pp. 11-16.

[15]A. Jakhrani, A.-K. Othman, A. Rigit, S. Samo, and S. Kamboh, "Estimation of carbon footprints from diesel generator emissions," in Green and Ubiquitous Technology (GUT), 2012 International Conference on, July 2012, pp. 78-81.

[16]Z. Chen and Y. Hu, "A hybrid generation system using variable speed wind turbines and diesel units," in Industrial Electronics Society, 2003. IECON '03. The 29th Annual Conference of the IEEE, vol. 3, Nov 2003, pp. 2729-2734 Vol.3.

[17]W. Koczara, G. Iwanski, B. Kaminski, M. Cirstea, and N. Brown, "Power distribution in res-diesel autonomous power system with doubly fed induction generator for reduction of fuel consumption," in Optimization of Electrical and Electronic Equipment, 2008. OPTIM 2008. 11th International Conference on, May 2008, pp. 339-344.

[18]A. Afzal, H. Kumar, and V. Sharma, "Hybrid renewable energy systems for energy security using optimization technique," in Utility Exhibition on Power and Energy Systems: Issues Prospects for Asia (ICUE), 2011 International Conference and, Sept 2011, pp. 1-6.

[19]A. Ahmadi and M. Pedrasa, "Optimal design of hybrid renewable energy system for electrification of isolated grids," in TENCON 2012 - 2012 IEEE Region 10 Conference, Nov 2012, pp. 1-6.

[20]I. Penava, S. Galijasevic, A. Muharemovic, and M. Penava, "Optimal design and demonstrative application of standalone hybrid renewable energy system," in Energy Conference (ENERGYCON), 2014 IEEE International, May 2014, pp. 960-967.

[21]A. Khodaei, "Provisional microgrids," Smart Grid, IEEE Transactions on, vol. 6 , no. 3, pp. 1107-1115, May 2015 .

[22]M. Hossain, M. Mahmud, H. Pota, N. Mithulananthan, and R. Bansal, "Distributed control scheme to regulate power flow and minimize interactions in multiple microgrids," in PES General Meeting Conference Exposition, 2014 IEEE, July 2014, pp. 1-5.

[23]F. Shahnia, R. Chandrasena, S. Rajakaruna, and A. Ghosh, "Autonomous operation of multiple interconnected microgrids with self-healing capability," in Power and Energy Society General Meeting (PES), 2013 IEEE, July 2013, pp. 1-5.

[24]H.-J. Yoo, H.-M. Kim, and C. H. Song, "A coordinated frequency control of lead-acid bess and li-ion bess during islanded microgrid operation," in
Vehicle Power and Propulsion Conference (VPPC), 2012 IEEE, Oct 2012, pp. 1453-1456.

[25]T. Saha and D. Kastha, "Design optimization and dynamic performance analysis of a stand-alone hybrid wind x2013; diesel electrical power generation system," Energy Conversion, IEEE Transactions on, vol. 25, no. 4, pp. 1209-1217, Dec 2010.

[26]P. Dokopoulos, A. Saramourtsis, and A. Bakirtzis, "Prediction and evaluation of the performance of wind-diesel energy systems," Energy Conversion, IEEE Transactions on, vol. 11, no. 2, pp. 385-393, Jun 1996.

[27]C. Rouyi, C. Jianbin, L. Jinyong, F. Chao, W. Ke, D. Weiguo, D. Xuzhu, and C. Guanglin, "System stability and its influencing factors analysis of the isolated wind-solar-diesel- battery hybrid micro-grid," in Electricity Distribution (CICED), 2012 China International Conference on, Sept 2012, pp. 1-4

[28]J. Shu, X. Zhang, C. Wu, and Y. L. Shen, "A significant scheme of distributed generation system using wind-solar-diesel applying in island," in Power Electronics Systems and Applications, 2009. PESA 2009. 3rd International Conference on, May 2009, pp. 1-3.

[29]A. Yogianto, H. Budiono, and I. Aditya, "Configuration hybrid solar system (pv), wind turbine, and diesel," in Power Engineering and Renewable Energy (ICPERE), 2012 International Conference on, July 2012, pp. 1-5.

[30]A. Chowdhury, M. Sajjad, and S. Saha, "Design of a stand-alone hybrid power system for a remote locality in bangladesh," in Electrical Computer Engineering (ICECE), 2012 7th International Conference on, Dec 2012, pp. 615-618

[31]M. El Badawe, T. Iqbal, and G. Mann, "Optimization and modeling of a stand-alone wind/pv hybrid energy system," in Electrical Computer Engineering (CCECE), 2012 25th IEEE Canadian Conference on, April 2012, pp. 1-6.

[32]U. Sureshkumar, P. Manoharan, and A. Ramalakshmi, "Economic cost analysis of hybrid renewable energy system using homer," in Advances in Engineering, Science and Management (ICAESM), 2012 International Conference on, March 2012, pp. 94-99

[33]LLC HOMER Energy. (2015, November) Homer energy. [Online]. Available: http://www.homerenergy.com/

[34]Ministerio del Interior y Seguridad Publica de Chile. (2015, November) Gobernacion provincia de choapa. [Online]. Available: http://www.gobernacionchoapa.gov.cl/info turismo/

[35]Banco Central de Chile, "Operaciones Financieras Indicadores," November 2015. [Online]. Available: \{http://www.bcentral.cl/es/faces/ofinanciaras \}.

[36]K. Kaplan and A. Stevens, "New opportunities from energy star x201c; connected x201d; appliances," in Consumer Electronics (ICCE), 2012 IEEE International Conference on, Jan 2012, pp. 81-82.

[37]US Department of Energy, "Kitchen appliances," Tech. Rep., November 2015. [Online]. Available: \{http://www.energy.gov/energysaver/tipskitchen-appliances $\}$

[38]Ministerio de Economia, Fomento y Reconstruccion. (1971) Nseg 9 en 71 alumbrado público en sectores urbanos.

[39]Ministerio de Economia, fomento y reconstruccin. (1978) Nseg 15.e.n 78. electricidad. especificaciones para iluminarias de calles y carreteras.

[40]Cronolab Unesco, Ed., Guia Practica de Iluminacion de Exteriores: Alumbrado Eficiente y Control de la Contaminacion Luminica, Tenerife Antofagasta, 2010.

[41]Departamento de Geofisica de la Universidad de Chile. (2015) Evaluacion del recurso solar.

[42]I. Petrovic and M. Vrazic, "Approach to advanced clearness index modelling," in Energy Conference (ENERGYCON), 2014 IEEE International, May 2014, pp. 937-942.

[43]Departamento de Geofisica de la Universidad de Chile, "Evaluacion del recurso eolico: Informe de viento," Universidad de Chile, Tech. Rep., 2015.

[44]J. Hermann-Josef, Wagner; Mathur, Green Energy and Technology; Introduction to Wind Energy Systems, Springer, Ed., 2009.

[45]Burton, T.; Sharpe, D.; Jenkins, N.; Bossanyi, E., Wind energy handbook, John Wiley \& Sons, Ed., 2001.

14 ${ }^{\text {th }}$ LACCEI International Multi-Conference for Engineering, Education, and Technology: "Engineering Innovations for 
[46]Homer Energy, "Parametros avanzados de recurso eolico," Tech. Rep., 2005.

[47]METEONORM 7, "Reporte de temperatura jaboneria," Tech. Rep., 2015.

[48]S. Giannoutsos and S. Manias, "A cascade control scheme for a grid connected battery energy storage system (bess)," in Energy Conference and Exhibition (ENERGYCON), 2012 IEEE International, Sept 2012, pp. 469-474.

[49]W. Shi, J. Jiang, S. Li, S. Lin, P. Lin, and F. Wen, "Applications of battery energy storage system (bess) for energy conversion base in expo 2010," in Power Electronics for Distributed Generation Systems (PEDG), 2010 2nd IEEE International Symposium on, June 2010, pp. 918-923.

[50]D. Budh and V. Virulkar, "Smoothing control for bess based hybrid renewable energy system," in Electrical, Electronics and Computer Science (SCEECS), 2014 IEEE Students' Conference on, March 2014, pp. $1-4$.

[51]X. Li, D. Hui, and X. Lai, "Battery energy storage station (bess)-based smoothing control of photovoltaic (pv) and wind power generation fluctuations," Sustainable Energy, IEEE Transactions on, vol. 4, no. 2, pp. 464-473, April 2013.

[52]National Renewable Energy Laboratory. (2015, November) pvwatts. [Online]. Available: http://pvwatts.nrel.gov/

[53]A. Elmahjoub, A. Ailane, M. Rachik, E. Labriji, A. Abouloifa, and A. Essadki, "A non-linear controller for single-phase dc-ac power converter using in the grid-connected photovoltaic," in Complex Systems (ICCS), 2012 International Conference on, Nov 2012, pp. 1-6.H. Ribeiro, A. Pinto, and B. Borges, "Single-stage dc-ac converter for photovoltaic systems," in Energy Conversion Congress and Exposition (ECCE), 2010 IEEE, Sept 2010, pp. 604-610.

[54]S. Okanuma, "Output electric power control of a magnetic oscillation type dc-ac converter," in Control and Modeling for Power Electronics (COMPEL), 2010 IEEE 12th Workshop on, June 2010, pp. 1-5.
D. Arcos-Aviles, J. Pascual, L. Marroyo, P. Sanchis, F. Guinjoan, and M. Marietta, "Optimal fuzzy logic ems design for residential grid-connected microgrid with hybrid renewable generation and storage," in Industrial Electronics (ISIE), 2015 IEEE 24th International Symposium on, June 2015, pp. 742-747.

[55]W. Shi, E.-K. Lee, D. Yao, R. Huang, C.-C. Chu, and R. Gadh, "Evaluating microgrid management and control with an implementable energy management system," in Smart Grid Communications (SmartGridComm), 2014 IEEE International Conference on, Nov 2014, pp. 272-277.

[56](2015, May) Centro de noticias. Instituto Nacional de Normalizacin Chile. [Online]. Available: http://www.inn.cl/noticias/index.php?id=230,

[57]Y. Ramgolam, S. Veerapen, V. Oree, A. Murdan, and K. Soyjaudah, "Energy profiles and performance of common electrical domestic appliances," in Energy Conference (ENERGYCON), 2014 IEEE International, May 2014, pp. 1129-1136.

[58]H. Energy. (2015, November) Modeling load growth. HOMER Energy Support. [Online]. Available: http://usersupport.homerenergy.com/customer/en/portal/articles/218876510206

[59]M. Ruiz, L. Velasco, J. Comellas, and G. Junyent, "Optical network net present value optimization in shared path protection environments," in Design of Reliable Communication Networks (DRCN), 2011 8th International Workshop on the, Oct 2011, pp. 38-45.

[60]W. Wetekamp, "Net present value (npv) as a tool supporting effective project management," in Intelligent Data Acquisition and Advanced Computing Systems (IDAACS), 2011 IEEE 6th International Conference on, vol. 2, Sept 2011, pp. 898-900.

14 ${ }^{\text {th }}$ LACCEI International Multi-Conference for Engineering, Education, and Technology: "Engineering Innovations for 